\title{
Polymorphism Candidate Genes of Indigenous Lien Minh Chickens
}

\section{Tran Thi Binh Nguyen ${ }^{1}$, Nguyen Huu Duc ${ }^{1}$, Vu Duc Quy ${ }^{1}$, Pham Thu Giang ${ }^{1}$, Nguyen Manh Linh ${ }^{2}$, Dinh Thi Ngoc Thuy ${ }^{3}$ and Nguyen Thi Dieu Thuy ${ }^{3}$}

\footnotetext{
${ }^{1}$ Faculty of Biotechnology, Vietnam National University of Agriculture, Hanoi 131000, Vietnam

${ }^{2}$ Institute of Marine Environment and Resources, Hai Phong 181810, Vietnam

${ }^{3}$ Institute of Biotechnology, Vietnam Academy of Science and Technology, Hanoi 122000, Vietnam
}

\begin{abstract}
Lien Minh chicken is an indigenous breed with several favorable properties, such as high productivity and good meat quality, and is associated with the economic development of the people in the Lien Minh village, Cat Hai, Hai Phong. The objective of the current research was to investigate the single nucleotide polymorphisms (SNPs) of candidate genes, which might be associated with broodiness and egg production traits. Ninety Lien Minh chicken individuals were genotyped for five SNPs of chicken prolactin $(P R L)$, Vasoactive Intestinal Peptide $(V I P)$, neuropeptide $\mathrm{Y}$ gene $(N P Y)$, growth hormone $(G H)$, and growth hormone receptor $(G H R)$ genes. Blood samples were used for DNA extraction and then for genotyping by the PCR-RFLP method. The allele frequencies obtained were as follows: 0.19 and 0.81 for alleles $\mathrm{C}$ and $\mathrm{T}(P R L-$ C2161G), respectively; in VIP (G5138982T), 0.55 for the $\mathrm{G}$ allele and 0.45 for T; in $G H$-SacI (the intron 4), 0.02 for A and 0.98 for B; and in GHR-NspI, 0.82 for C and 0.18 for T. The NPY gene (four nucleotide indel) had the frequencies of 0.86 for I and 0.14 for $\mathrm{D}$. The four studied polymorphic loci ( $P R L, V I P, N P Y$, and $G H)$ were in Hardy-Weinberg equilibrium in the Lien Minh chicken population. These are the initial results, which can be used to analyze the correlation of molecular markers and egg production traits in Lien Minh chickens.
\end{abstract}

\section{Keywords}

Lien Minh chicken, PCR-RFLP, candidate genes, single nucleotide polymorphisms.

Received: March 16, 2018

Accepted: September 07, 2018

\section{Correspondence to} ttbnguyen@vnua.edu.vn ntdthuy@ibt.ac.vn

\section{Introduction}

Lien Minh chicken is a native breed of Lien Minh village, Tran Chau commune, Cat Hai district, Haiphong city, Viet Nam. This is a chicken with beautiful features, nice feather color, yellow skin, 
good meat quality, and a thin fat layer under the skin. The Lien Minh chicken was assessed at the level of dangerous threat (FAO, 2007), and has been listed on the conservation list since 2008. Since 2013, polices concerning the conservation and effective use of Lien Minh chicken have been carried out. The production capacity of Lien Minh chicken eggs is relatively low compared to other native chickens, with an average of 75.6 eggs/hen/year (Doan et al., 2016).

To study the low reproductive rate in Lien Minh chickens, candidate genes, the loci associated with reproductive traits, were selected derived from the knowledge of reproductive physiology and reports as to whether these genes showed an association with reproductive performance in commercial poultry lines. Prolactin is a polypeptide hormone secreted by the anterior pituitary gland, which is involved in many physiological pathways: osmotic regulation, luteolysis (regressive ovary), and the maintenance of incubation behavior in hens. Studies have shown that the $P R L$ is present in the hypothalamus, the pituitary gland, the oviduct, and the egg, with the highest levels found in the pituitary gland (Li et al., 2009a). In chickens, the hormone prolactin is one of the hormones that plays an important role in egg production. Prolactin concentrations increase sharply in plasma, may induce broody behavior (Sockman et al., 2000), and results in reduced egg production (Reddy et al., 2002). A mutation that occurs in the promoter region can affect the expression of the PRL gene, so it may affect egg production. Prolactin secretion in birds is predominantly regulated by releasing factors, one of which is a vasoactive intestinal peptide (Kagya-Agyemang et al., 2012). Vasoactive intestinal peptide (VIP) is a prolactin-releasing factor in birds (El Halawani et al., 1990; 1997). VIP increases $P R L$ secretion from pituitary glands, especially when the pituitary gland responsiveness is enhanced with estrogen pretreatment (Sharp et al., 2005). VIP binds with the vasoactive intestinal peptide receptor to give rise to the secretion and release of $P R L$ (El Halawani et al., 1990). Neuropeptide Y (NPY) is an important neuromodulator, which is associated with gonadal function in birds and mammals (Hilal et al., 1996). NPY may affect the egg production rate through its role in controlling ovulation (Dunn et al., 2004). Genetic encoding for the neuropeptide $\mathrm{Y}$ gene is associated with the age of having the first egg and the number of eggs laid (Xu et al., 2011a, $\mathrm{Xu}$ et al., 2011b, Dunn et al., 2004, Li et al., $2009 \mathrm{~b})$. The NPY gene might produce markers for the age of the onset of lay, and through its role in the control of ovulation, influence the egg production rate. Injections of $N P Y$ change the plasma concentration of the luteinizing hormone and growth hormone (Pierroz et al., 1996), suggesting that it may play a significant role in the secretion of these hormones (Wang et al., 2001). Growth hormone $(G H)$, when combined with the growth hormone receptor in the liver and when forming the GH-GHR-IGFs signal pathway, affects chicken development (Lau et al., 2007). The identified alleles of the GH gene of White leghorn have been linked to the egg production phenotype (Kuhnlein et al., 1997). The growth hormone receptor $(G H R)$ controls the number of follicles in animals that are recruited to the rapid growth phase (Roberts et al., 1994; Monget et al., 2002).

The aim of this study was to investigate polymorphisms in the $P R L, V I P, N P Y, G H$, and $G H R$ genes, that are associated with egg production traits in Lien Minh chicken. These are the initial results, which can be used to analyze the correlation of molecular markers and egg production traits in Lien Minh chickens in a larger population, and to provide information to support the breeding and development of the Lien Minh chicken.

\section{Materials and Methods}

\section{Experimental animals}

This experiment was conducted on Lien Minh indigenous chickens, which were raised at an experimental farm at the Center of Applied Science and Technology, Hai Phong. A total of 90 hens were studied, which were hatched from eggs collected in Lien Minh village (from 15 households). 


\section{DNA extraction and PCR amplification}

Chicken blood samples from individuals were collected in anti-coagulant tubes with EDTA and stored at $4^{\circ} \mathrm{C}$. Genomic DNA was extracted by a standard procedure using Proteinase $\mathrm{K}$ digestion followed by phenol-chloroform extraction and precipitation with ethanol (Ausubel et al., 1995). Based on the primer sequences that have been previously published, information for primer pairs and polymorphisms are shown in Table 1 and Table 2.

PCR was performed in a $25 \mu \mathrm{L}$ reaction containing 1x PCR Buffer, $1.5 \mathrm{mM} \mathrm{MgCl}_{2}, 1.25$ $\mathrm{mM}$ each dNTPs, $5 \mathrm{pM}$ forward and reverse primers, 1U Taq-polymerase (Fermentas), and 100 ng genomic DNA. In PCR amplification, an initial denaturation at $94^{\circ} \mathrm{C}$ for $3 \mathrm{~min}$ followed by 35 cycles of denaturation at $94^{\circ} \mathrm{C}$ for $45 \mathrm{sec}$, annealing for $45 \mathrm{sec}$, and extension at $72^{\circ} \mathrm{C}$ for $90 \mathrm{sec}$, and an additional extension of $72^{\circ} \mathrm{C}$ for 7 min was set. The PCR products were digested with restriction enzymes (RE) overnight at $37^{\circ} \mathrm{C}$ for all enzymes. The restriction fragments were separated on $2.0 \%$ agarose gel.

\section{Statistical analyses}

The data were recorded using Excel software. The gene frequencies were calculated by the counting method as: $\mathrm{p}=2(\mathrm{AA})+$ $(\mathrm{AB}) / 2 \mathrm{~N}$ and $\mathrm{q}=2(\mathrm{BB})+(\mathrm{AB}) / 2 \mathrm{~N}$ where $\mathrm{p}=$ the gene frequency of allele $A, q=$ the gene frequency of allele $\mathrm{B}$, and $\mathrm{N}=$ the total number of chickens tested. The Hardy-Weinberg Equilibrium (HWE) was estimated using the method of Rodriguez et al. (2009) (http://www.oege.org/software/hwe-mrcalc.shtml).

\section{Results and Discussion}

\section{PCR-RFLP analysis}

Figure 1 shows the results of the PCRRFLP analysis of the candidate genes. Bands in the gels represent the distinguishable genotypes in each of the polymophisms observed. In detail: two genotypes were found at the sites of $G H / \mathrm{SacI}(\mathrm{AB}, \mathrm{BB})$ and GHR/NspI (CC, TT), and three genotypes at the sites of PRL/Csp6I (CC, CG, GG), VIP/ApoI (GG, TG, TT), and NPY/DraI (II, ID, DD).

Table 1. Information for primers and polymorphisms

\begin{tabular}{|c|c|c|c|c|}
\hline Locus & Polymorphism & Sequence $\left(5^{\prime}-3^{\prime}\right)$ & $\mathrm{Ta}\left({ }^{\circ} \mathrm{C}\right)$ & GenBank $\left(\mathrm{N}^{\circ}\right)$ \\
\hline \multirow[t]{2}{*}{$P R L$} & C2161G & F: AGAGGCAGCCCAGGCATTTTAC & 56 & AB011438 \\
\hline & & R: CCTGGGTCTGGTTTGGAAATTG & & \\
\hline \multirow[t]{2}{*}{ VIP } & G5138982T & F: GCTTGGACTGATGCGTACTT & 55 & NC_006090 \\
\hline & & R: GTATCACTGCAAATGCTCTG & & \\
\hline \multirow[t]{2}{*}{ NPY } & AATA Indel & F: TCTCAGAGCTCCAACGTATGA & 56 & M87298 \\
\hline & (I3139135D) & R: ATATTTCTGTGCCTGAACAACA & & \\
\hline \multirow[t]{2}{*}{$\mathrm{GH}$} & C-2983T & F: CTAAAGGACCTGGAAGAAGGG & 61 & NC_006114 \\
\hline & & R: AACTTGTCGTAGGTGGGTCTG & & \\
\hline \multirow[t]{2}{*}{$G H R$} & C571T & F: ACGAAAAGTGTTTCAGTGTTGA & 60 & NC_006127 \\
\hline & & R: TTTATCCCGTGTTCTCTTGACA & & \\
\hline
\end{tabular}

Note: F: Forward primer; R: Reverse primer; Ta: Annealing temperature; $N^{\circ}$ : accession number.

Table 2. Information for the restriction enzymes and PCR-RFLP size

\begin{tabular}{clccl}
\hline Locus & \multicolumn{1}{c}{ PCR-RFLP size $(\mathrm{bp})$} & $\mathrm{T}\left({ }^{\circ} \mathrm{C}\right)$ & $\mathrm{RE}$ & \multicolumn{1}{c}{ Reference } \\
\hline PRL & $439 / 405 / 34$ & 37 & Csp6l & Cui et al. (2006) \\
VIP & $520 / 486 / 34$ & 37 & Apol & Xu et al. (2011a) \\
NPY & $248(252) 167 / 81$ & 37 & Dral & Xu et al. (2011a) \\
GH & $1164 / 1020 / 570 / 450 / 144$ & 37 & Sacl & Makhsous et al. (2013) \\
GHR & $740 / 571 / 169$ & 37 & Nspl & Li et al. (2008) \\
\hline
\end{tabular}

Note: RE: restriction enzyme. 
For the insertion/deletion mutation of four nucleotides in the NPY gene, the PCR product resulted in two DNA bands with the molecular sizes of 252 bp (insertion) or 248 bp (deletion). The PCR product of the NPY/DraI offered two types of cutting: 252 bp (NPY/252 bp no cut point with $S a c \mathrm{I})$ and $167 / 81$ bp (NPY/248bp cut with $S a c \mathrm{I}$ ), which corresponded to two I and D alleles, respectively. The $G H$ gene contained two cut sites with SacI, but only one polymorphic cut site. Specifically, when the products were separated on $2 \%$ agarose for the two types of cutting the sizes were 570/450/144 bp or $1020 / 144 \mathrm{bp}$, corresponding to the A and B

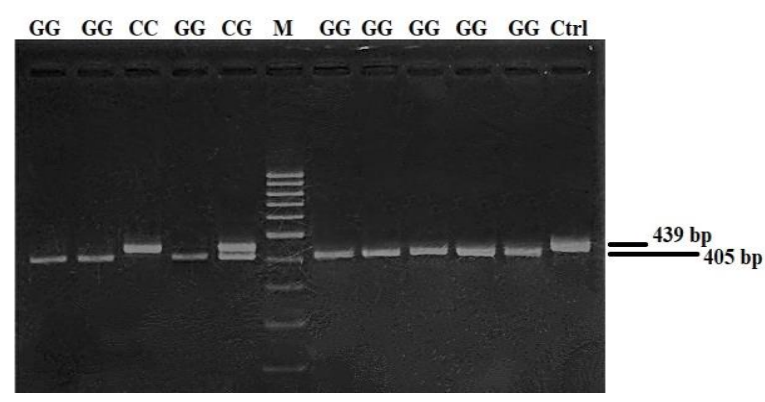

PRL/Csp6l, CC: 439 bp; CG: 439/405/34 bp; GG: 405/34 bp

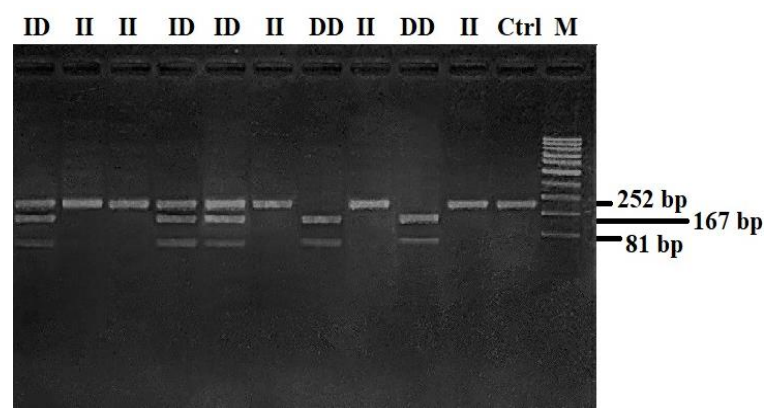

NPY/Dral, II: 252 bp; ID: 252/167/81 bp; DD: 167/81 bp alleles, respectively, which were in accordance with results reported by Kansaku et al. (2003). The SNPs of the VIP gene were genotyped after digestion of the PCR products with the restriction enzyme ApoI. The restriction fragment lengths for the $\mathrm{T}$ and $\mathrm{G}$ alleles of the VIP/ApoI locus were 520 and $486 / 34 \mathrm{bp}$. The following DNA restriction fragments were obtained for the $G H R$ NspI polymorphism: $571 / 169$ bp for the CC genotype and $740 \mathrm{bp}$ for the TT genotype. In the case of the single nucleotide polymorphisms at position $\mathrm{C} 2161 \mathrm{G}$ in the prolactin gene, there were fragments of $439 \mathrm{bp}$ and $405 / 34 \mathrm{bp}$ in size, indicating the $\mathrm{C}$ and $\mathrm{G}$ alleles (Figure 1).

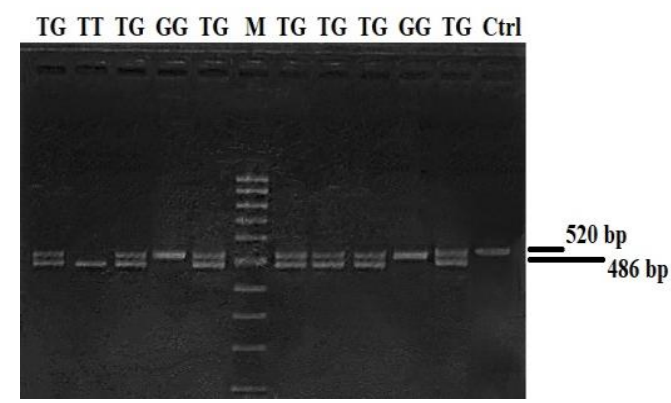

VIP/Apol, GG: 520 bp; TG: 520/486 bp; TT: 486 bp

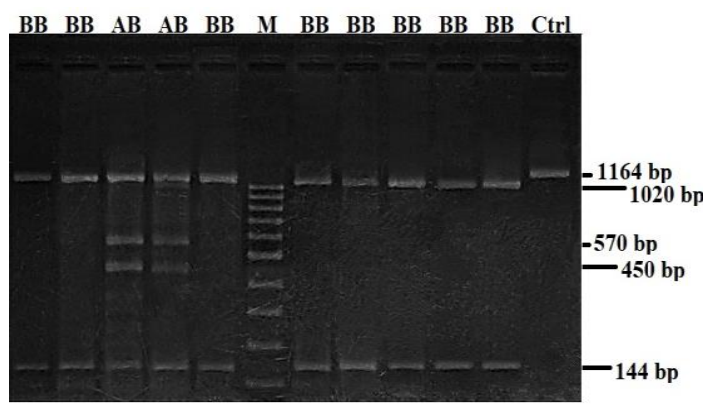

GH/Sacl, BB: 1020 bp; AB: 1020/570/450/144 bp

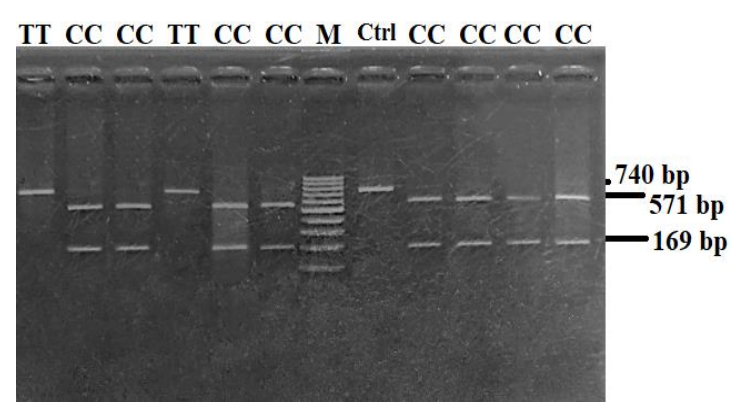

GHR/Nspl, TT: 740 bp, CC: $751 / 169$ bp

Note: M: 100-bp DNA ladder, Fermentas; Ctrl: PCR product.

Figure 1. PCR-RFLP analysis of candidate genes 


\section{Genotypic and allelic frequencies}

The frequencies of the alleles and genotypes of the loci tested are presented in Table 3. In this study, four single nucleotide polymorphisms (SNPs) and one indel (insertion/deletion) belonging to five candidate genes were identified from Lien Minh chickens. The results also showed that the observed distribution of genotypes in the four loci $(P R L$, $V I P, N P Y$, and $G H)$ were not significantly different from the distribution expected under the assumption of Hardy Weinberg equilibrium $(P>0.05)$. This study only analyzed samples from Lien Minh hens, thus genotypic frequencies of GHR/NspI were not appropriate for use with the GHR locus because this locus is sex-linked. The growth hormone receptor $(G H R)$ gene is located on the $\mathrm{Z}$ chromosome, which determines the hemizygous state in hens (Table 3).

For the PRL, the number of Lien Minh chickens that had $\mathrm{C}$ allele accounted for a low proportion of the population (0.19). The frequency of allele $\mathrm{C}$ of $P R L$ appears to be quite different in chicken breeds. A study on six Chinese chicken breeds showed that the frequency of allele $\mathrm{C}$ appeared to have a wide range, 0.05 (Yangshan), 0.13 (Taihe Silkies 2), 0.3 (Taihe Silkies 1), 0.35 (White Rock), 0.42 (Nongdahe), and 1.00 in White Leghorn chickens. Analysis of SNPs located in PRL carried out by Cui et al. (2006) showed that a high-frequency of the $\mathrm{C}$ allele in Chinese chickens gave better egg yields. Specifically, Taihe Silkies and Yangshan chickens, which are Chinese native breeds with strong broodiness, produced less than 90 eggs/hen/year. On the other hand, the Nongdahe and White Leghorn chicken breeds produced 160 and 300 eggs/hen/year, respectively. The frequency of the $\mathrm{C}$ allele was found in a Vietnamese chicken, Noi chickens (0.33), which produced 40-50 eggs/hen/year (Ngu et al., 2015). Therefore, it may be assumed that the $\mathrm{C}$ allele at position 2161 of $P R L$ affected egg production by regulating reproduction in the chickens.

Previous reports have shown that active immunization with VIP could increase reproduction yield eggs in turkeys (El Halawani et al., 1995; Caldwell et al., 1999). A polymophism of the VIP gene was shown to associate with reproducing eggs and the hatching habit of chickens (Johnson et al., 1999). Polymorphisms at the position VIP/ApoI were linked to egg number at 300 days of age (Xu et al., 2011a). Zhou et al. (2010) also showed that an indel of 3 nucleotides (AGG) in the $5^{\prime}$ regulatory region of the VIP gene was associated with reproduction yield eggs at 300 days of age. The presence of a medium frequency of the $\mathrm{G}$ allele found in Lien Minh chickens (0.55) was in accordance with Ningdu

Table 3. Allele and genotype frequencies of genes in Lien Minh chickens $(n=90)$

\begin{tabular}{|c|c|c|c|c|c|c|c|c|c|}
\hline \multirow{2}{*}{ Locus } & \multicolumn{5}{|c|}{ Observed population } & \multicolumn{3}{|c|}{ Expected population } & \multirow{2}{*}{ HWE $x^{2}$} \\
\hline & \multicolumn{3}{|c|}{ Genotype } & \multicolumn{2}{|c|}{ Allele } & \multicolumn{3}{|c|}{ Genotype } & \\
\hline \multirow[t]{2}{*}{$P R L$} & $\mathrm{CC}$ & $C G$ & GG & $\mathrm{C}$ & $\mathrm{G}$ & $\mathrm{CC}$ & $C G$ & GG & $0.29^{\text {ns }}$ \\
\hline & 0.04 & 0.29 & 0.67 & 0.19 & 0.81 & 0.04 & 0.31 & 0.66 & \\
\hline \multirow[t]{2}{*}{$N P Y$} & DD & ID & II & $\mathrm{D}$ & 1 & DD & ID & II & $3.28^{\text {ns }}$ \\
\hline & 0.04 & 0.20 & 0.76 & 0.14 & 0.86 & 0.02 & 0.25 & 0.73 & \\
\hline \multirow[t]{2}{*}{ VIP } & TT & GT & GG & G & $\mathrm{T}$ & TT & GT & GG & $1.60^{\text {ns }}$ \\
\hline & 0.21 & 0.57 & 0.22 & 0.55 & 0.45 & 0.24 & 0.50 & 0.26 & \\
\hline \multirow[t]{2}{*}{$G H$} & AA & $A B$ & BB & A & B & AA & $A B$ & BB & $0.03^{\text {ns }}$ \\
\hline & 0.00 & 0.03 & 0.97 & 0.02 & 0.98 & 0.00 & 0.03 & 0.97 & \\
\hline \multirow[t]{2}{*}{$G H R$} & $\mathrm{CC}$ & CT & $\mathrm{TT}$ & C & $\mathrm{T}$ & $\mathrm{CC}$ & CT & $\mathrm{TT}$ & - \\
\hline & 0.82 & 0.00 & 0.18 & 0.82 & 0.18 & 0.68 & 0.29 & 0.03 & \\
\hline
\end{tabular}

Note: HWE: Hardy-Weinberg equilibrium, $n$ : number of individuals: ${ }^{n s}$ : $P>0.05$, Data were not appropriate to Hardy-Weinberg Equilibrium analysis. 
Sanhuang chickens (0.57) and was higher than that of Noi chickens (0.44) (Xu et al., 2011; Vu and Ngu, 2016).

The observed genotypic frequencies at the NPY/DraI site in Lien Minh chickens were II (0.76), ID (0.20), and DD (0.04). The NPY/DraI ID heterozygous individuals had an earlier age for laying compared to the DD and II homozygous genotypes (Dunn et al., 2004). The four nucleotide indel of the NPY gene also showed a genetic correlation with the number of eggs at 300 days of age (Li et al., 2009b). In a study by Abdi et al. (2014), chickens with the II genotype produced many more eggs until 300 days of age $(P<0.05)$. The association of the NPY/DraI gene with egg reproduction traits in Noi chickens was also observed by Ngu et al. (2015). Thus, these data suggest that the four nucleotide indel in NPY could be considered a candidate gene related to the number of eggs laid in chickens.

The $G H$ fragment, after being digested with the SacI restriction enzyme, produced four fragments with the lengths $1020,570,450$, and $144 \mathrm{bp}$, which is in accordance with results reported by Kansaku et al. (2003). Results for the genotype calculations of $G H$ on Lien Minh chickens showed that $\mathrm{BB}$ genotype frequency was 0. 97, while $A B$ genotype accounted for only 0.03 , and there was no AA genotype. The frequencies of the $\mathrm{A}$ and $\mathrm{B}$ alleles were 0.02 and 0.98 , respectively. The genotyping results in the Lien Minh chickens were similar to those of both Ukrainian Poltava Clay chickens, with the genotype frequencies of $\mathrm{AB}(0.070)$ and $\mathrm{BB}$ (0.930), and allele frequencies of $A(0.036)$ and B (0.964), and Noi chickens, in which the AA genotype was absent and the $\mathrm{AB}$ genotype frequency was only 0.02 . Therefore, the frequency of the B allele was up to 0.99 while the A allele only existed at $0.01(\mathrm{Vu}$ and $\mathrm{Ngu}$, 2016). A similar trend was found in a local Iran chicken genotype, with the frequencies of AA (0.021), AB (0.162), and BB (0.817), and the allele frequencies of $A(0.102)$ and $B(0.898)$. Reproduction yield eggs of the $\mathrm{AB}$ genotype of the local Iran chicken significantly differed from the $\mathrm{AA}$ and $\mathrm{BB}$ genotypes $(P>0.05)$ (Makhsous et al., 2013).
The growth hormone receptor $(G H R)$ gene is located in the $\mathrm{Z}$ chromosome, (Zhang et al., 2016), which determines the hemizygous state in hens, thus there was no heterozygous $A B$ in 90 Lien Minh hen individuals. The results of previous studies showed that the Ukrainian chicken Poltava Clay had genotype frequencies of A0 (0.28) and B0 (0.72) (Kulibaba et al., 2015) and Wenchang Chinese Chicken Breeds had genotypic frequencies of A0 (0.20) and B0 (0.80) (Li et al., 2008). However, in a study in the Mazandaran chicken, the results showed that the occurrence of genotype A0 (0.99) was significantly higher than that of genotype B0 (0.01) (Babak and Ghodrat, 2009). Natural mutations in the GHR gene often alter the rate of ovulation (Reddy and Siegel, 1977), the ability to lay eggs (Nagaraja et al., 2000), the number of double-yolked eggs (Hocking et al., 1994), and the age at first egg (Feng et al., 1997). Thus, GHR can be considered a candidate gene for reproductive traits in chickens.

\section{Conclusions}

In conclusion, our analysis observed the polymorphisms of five candidate genes in Lien Minh chickens. The observed distribution of the genotypes in four loci (PRL, VIP, NPY, and $G H)$ were not significantly different from the distribution expected under the assumption of Hardy Weinberg equilibrium $(P>0.05)$. These loci should be used for purpose of association studies between genotype/allele and egg reproduction traits in Lien Minh chickens.

\section{Acknowledgements}

This study was funded from a grant of scientific research of the Vietnam National University of Agricultural (T2018-12-83), and the Science and Technology Cooperation Program (VAST.NPP.01/15-16-Vietnam Academy of Science and Technology).

\section{References}

Ausubel F. M., Brent R., Kingston R. E., Moore D. D., Seidman J. G., Smith J. A. and Struhl K. (1995). 
Short Protocols in Molecular Biology $3^{\text {rd }}$ ed. John Wilet \& Sons Inc, New York.

Babak E. and Ghodrat R. M. (2009). Genomic growth hormone, growth hormone receptor and transforming growth factor $\beta-3$ gene polymorphism in breeder hens of Mazandaran native fowls. African Journal of Biotechnology. Vol 8 (14). pp. 3154-3159.

Caldwell S. R., Johnson A. F., Yule T. D. and Grimes J. L. (1999). Increased egg production in juvenile turkey hens after active immunization with vasoactive intestinal peptide. Poultry Science. Vol 78. pp. 899901.

Cui J. X., Du H. L., Liang Y., Deng X. M., Li N. and Zhang X. Q. (2006). Association of polymorphisms in the promoter region of chicken prolactin with egg production. Poultry Science. Vol 85. pp. 26-31.

Doan B. H., Dang P. K., Tuan H. A. and Thinh N. H. (2016). Lien Minh chicken breed and live hood of people on Cat Hai Island district Hai Phong city Vietnam: Characterization and prospects. Animal Genetics and Breeding. Vol 209. pp. 26-31.

Dunn I. C., Miao Y. W., Romanov M. N., Wilson P. W. and Walddington D. (2004). A study of association between genetic markers in candidate genes and reproductive traits in one generation of a commercial broiler breeder hen population. Heredity. Vol 92. pp. 128-134.

El Halawani M. E., Silsby J. L. and Mauro L. J. (1990). Vasoactive intestinal peptide is a hypothalamic prolactin releasing neuropeptide in the turkey (Meleagris gallopavo). General and Comparative Endocrinology. Vol 78. pp. 66-73.

El Halawani M. E., Silsby J. L., Rozenboim I. and Pitts G. R. (1995). Increased egg production by active immunizationagainst vasoactive intestinal peptide in the turkey (Meleagris gallopavo). Biology of Reproduction. Vol 52. pp. 179-183.

El Halawani, M. E., Youngren O. M. and Pitts G. R. (1997). Vasoactive intestinal peptide as the avian prolactin releasing factor. In: Etches R. and Harvey S. (Ed.). Perspectives in Avian Endocrinology. The Society of Endocrinology, Bristol, United Kingdom. pp. 403-416.

FAO (2007). The State of the World's Animal Genetic Resources for Food and Agriculture, edited by Rischkowsky B. and Pilling Rome. Retrieved on January 2, 2017 at http://www.fao.org/docrep/010/ a1250e/a1250e00.htm.

Feng X. P., Kuhnlein U., Aggrey S. E., Gavora J. S. and Zadworny D. (1997). Trait association of genetic markers in the growth hormone and the growth hormone receptor gene in a White Leghorn strain. Poultry Science. Vol 76 (12). pp. 1770-1775.

Hilal E. M., Chen J. H. and Silverman A. J. (1996). Join migration of gonaldotropin-releasing hormone $(\mathrm{GnRH})$ and neuropeptide Y (NPY) neurons from olfactory placode to central nervous system. Journal of Neurobiology. Vol 31. pp. 487-502.

Hocking P. M., Bernard R., Wilkie R. S. and Goddard C. (1994). Plasma growth hormone and insulin-like growth factor-I (IGF-I) concentrations at the onset of lay in ad libitum ad restricted broiler breeder fowl. British Poultry Science. Vol 35. pp. 299-308.

Johnson A., Yule T., Grimes J., Ficken M. and Christensen V. (1999). Increased egg production in juvenile turkey hens after active immunization with vasoactive intestinal peptide. Poultry Science. Vol 78. pp. 899-901.

Kagya-Agyemang J. K., Shendan S. and Yinzuo B. (2012). Studies on the endocrine and neuroendocrine control of broodiness in the Yuehuang Hen. International Journal of Poultry Science. Vol 11. pp. 488-495.

Kansaku N., Nakada A., Okabayashi H., Guemene D. and Kuhnlein U. (2003). DNA polymorphism in the chicken growth hormone gene: Association with egg production. Animal Science Journal. Vol 74. pp. 243244.

Kuhnlein U., Liu N., Weigend S., Gavora J.S., Fairfull W. and Zadworny D. (1997). DNA polymorphisms in the chicken growth hormone gene: response to selection for disease resistance and association with egg production. Animal Genetics. Vol 28. pp. 116-123.

Kulibaba R. A. (2015). Polymorphism of growth hormone, growth hormone receptor, prolactin and prolactin receptor genes in connection with egg production in Poltava clay chicken. Agricultural Biology. Vol 50. pp. 198-207.

Lau J. S., Yip C. W., Law K. M. and Leung F. C. (2007). Cloning and characterization of chicken growth hormone binding protein (cGHBP). Domestic Animal Endocrinology. Vol 33. pp. 107-121.

Li H. F., Zhu W. Q., Chen K. W., Wu X., Tang Q. P., Gao Y. S., Song W. T., Xu W. J. and Xu H. L. (2009b). Polymorphism in NPY and IGF-I genes associate with reproductive traits in Wenchang chicken. African Journal of Biotechnology. Vol 8. pp. 47444748.

Li H. F., Zhu W. Q., Chen K. W., Wu X., Tung Q. P. and Gao Y. S. (2008). Associations between GHR and IGF-1 gene polymorphisms, and reproductive traits in Wenchanf chickens. Turkish Journal of Veterinary and Animal Sciences. Vol 32 (4). pp. 281-285.

Li H. F., Zhu W. Q., Chen K. W., Zhang T. J. and Song W. T. (2009a). Association of polymorphisms in the intron 1 of duck prolactin with egg performance. Turkish Journal of Veterinary and Animal Sciences. Vol 33. pp. 193-197.

Makhsous S. G., Mirhoseini S. Z., Zamiri M. J. and Niazi A. (2013). Polymorphisms of growth hormone gene in a native chicken population: association with egg production. Bulletin of the Veterinary Institute in Pulawy. Vol 57. pp. 73-77.

Monget P., Fabre S., Mulsant P., Lecerf F., Elsen J. M., 
Mazerbourg S., Pisselet C. and Monniaux D. (2002). Regulation of ovarian folliculogenesis by IGF and BMP system in domestic animals. Domestic Animal Endocrinology. Vol 23. pp. 139-154.

Nagaraja S. C., Aggrey S. E., Yao J., Zadworny D., Fairfull R. W. and Kuhnlein U. (2000). Trait association of a genetic marker near the IGF-I gene in egg-laying chickens. The Journal of Heredity. Vol 91. pp. 150-156.

Ngu N. T., Xuan N. H., Vu C. T., An N. T., Dung T. N. and Nhan N. T. H. (2015). Effects of genetic polymorphisms on egg production in indigenous Noi chicken. Journal of Experimental Biology and Agricultural Science. Vol 3 (4). pp. 487-493.

Pierroz D. D., Catzeflis C., Aebi A. C. and Rivier J. E. (1996). Chronic administration of neuropeptide Y into the lateral ventricle inhibits both the pituitarytesticular axis and growth hormone and insulin-like growth factor I secretion in intact adult male rats. Endocrinology. Vol 137. pp. 3-12.

Reddy I. J., David C. G. and Sarma P. V. (2002). Singh K The possible role of prolactin in laying performance and steroid hormone secretion in domestic hen (Gallus domesticus). General and Comparative Endocrinology. Vol 127. pp. 249-255.

Reddy P. R. K. and Siegel P. B. (1977). Selection for body weight at eight weeks of age. Effects of the sex-linked dwarf gene. Poultry Science. Vol 56. pp. 1004-1013.

Roberts R. D, Sharp P. J., Burt D. W. and Goddard C. (1994). Insulin-like growth factor-1 in the ovary of the laying hen: gene expression and biological actions on granulosa and thecal cell. General and Comparative Endocrinology. Vol 93. pp. 327-336.

Rodriguez S., Gaunt T. R. and Day I. N. M. (2009). Hardy-Weinberg equilibrium testing of biological ascertainment for Mendelian randomization studies. American Journal of Epidemiology. Vol 169. pp. 505514.
Sharp P. J., Macnamee M. C., Talbotr R. T., Sterlingr R. J. and Hallt T. R. (2005). Aspects of the neuroendocrine control of ovulation and broodiness in the domestic hen. The Journal of Experimental Zoology. Vol 232. pp. 475-483.

Sockman K. W., Schwabl H. and Sharp P. J. (2000). The role of prolactin in the regulation of clutch size and onset of incubation behavior in the American kestrel. Hormones and Behavior. Vol 38. pp. 168-176.

Vu C. T. and Ngu N. T. (2016). Single nucleotide polymorphisms in candidate genes associated with egg production traits in native Noi chicken of Vietnam. International Journal of Plant, Animal and Environmental Sciences. Vol 6. pp. 162-169.

Wang X., Day J. R. and Vasilatos-Younken R. (2001). The distribution of neuropeptide $\mathrm{Y}$ gene expression in the chicken brain. Molecular and Cellular Endocrinology. Vol 174. pp. 129-136.

Xu H., Zeng H., Zhang D., Jia X., Luo C., Fang M., Nie Q. and Zhang X. (2011a). Polymorphisms associated with egg number at 300 days of age in chickens. Genetics and Molecular Research. Vol 10. pp. 22792289.

Xu H., Zeng H., Luo C., Zhang D., Wang Q., Sun L., Yang L., Zhou M., Nie Q. and Zhang X. (2011b). Genetic effects of polymorphisms in candidate genes and the QTL region on chicken age at first egg. BMC Genetics. Vol 12. pp. 33-42.

Zhang L., Lin S., An L., Ma J., Qiu F., Jia R., Nie Q., Zhang D., Luo Q., Li T., Wang Z. and Zhang Z. (2016). Chicken GHR natural antisense transcript regulates $G H R$ mRNA in LMH cells. Oncotarget. Vol 7 (45). pp 73607-73617.

Zhou M., Du Y., Nie Q., Liang Y., Luo C., Zeng H. and Zhang X. (2010). Associations between polymorphisms in the chicken VIP gene, egg production and broody traits. British Poultry Science. Vol 51. pp. 195-203. 